Maciej Bachryj-Krzywaźnia

Uniwersytet Wrocławski

\title{
Antropodoksa polityczna jako kategoria teoretyczna i przedmiot badań
}

DOI: $10.19195 / 1643-0328.23 .2$

Słowa kluczowe: antropodoksa, antropologia potoczna, narracja, wiedza potoczna, natura ludzka, psychologia potoczna

\section{Wprowadzenie}

Na wstępie pragnę zaznaczyć, że świadom jestem tego, iż niektóre z zawartych w niniejszym artykule twierdzeń mają charakter spekulatywny i wymagają empirycznej weryfikacji. W tym sensie należy je traktować jako pewien projekt badawczy, którego realizacja pozwoliłaby stawiane dalej tezy przetestować. Ponadto należy zaznaczyć, że różne aspekty dyskutowanych zagadnień są przedmiotem refleksji badaczy różnych dyscyplin i orientacji teoretycznych. Na wstępie pragnę też zadeklarować swoje stanowisko, aby uniknąć nieporozumień. Niniejszy tekst pisany jest z pozycji psychologii polityki orientacji poznawczej, koncentruje się na indywidualnych aspektach procesów poznawczych oraz ich wpływie na zachowania polityczne. $Z$ racji ograniczeń objętościowych artykułu inne możliwe tu perspektywy teoretyczne zostaną pominięte.

Rozpocznę spostrzeżeniem Andrew Heywooda, który stwierdza, iż

prawie każda doktryna polityczna czy przekonanie zasadza się na pewnej teorii natury ludzkiej, niekiedy formułowanej w sposób wyraźny, często zaś po prostu dorozumianej. Modele natury ludzkiej znacząco różnią się od siebie. Każdy z nich ma diametralnie odmienne implikacje w zakresie pożądanej organizacji życia politycznego i społecznego ${ }^{1}$.

Nie jest to jedyny badacz, który dostrzega rolę, jaką w myśli politycznej odgrywa koncept natury ludzkiej. Lyman Tower Sargent, badając i porównując z sobą ideologie, proponuje pewien zestaw pytań jako swoiste narzędzie badawcze. Jedne z pierwszych na tej liście dotyczą właśnie natury ludzkiej — jaka ona jest i jak wpływa na system polityczny $^{2}$. Chociaż nie zawsze w pracach poświęconych ideologiom politycznym kwestia

1 A. Heywood, Teoria polityki. Wprowadzenie, Warszawa 2009, s. 27.

2 L. Tower Sargent, Political Ideologies. A Comparative Analysis, Wadsworth 2009, s. 13-15. 
natury ludzkiej postawiona jest w sposób tak bezpośredni, to koncept ten jest $\mathrm{w}$ nich silnie obecny. Często stanowi jeden z wątków ideologii, który jest w mniej lub bardziej zdawkowej formie przywoływany przez badaczy jako element uzasadniający i wyjaśniający inne ideologiczne postulaty ${ }^{3}$.

Przytoczone słowa brytyjskiego badacza uzmysławiają nam dwie kwestie. Po pierwsze, działania polityczne, wszelkie interwencje podejmowane przez ludzi w sferze polityki, które przeprowadzane są w celu realizacji określonego planu, programu, agendy ideologiczno-doktrynalnej, są ostatecznie zakorzenione w twierdzeniach o charakterze antropologicznym. Uzasadnieniem realizacji określonej wizji stosunków społeczno-politycznych jest $\mathrm{w}$ tej perspektywie wypowiedziane wprost lub dorozumiane przekonanie, że człowiek posiada określone potrzeby, dążenia, właściwości, które najpełniej będą się realizować w takiej właśnie rzeczywistości społeczno-politycznej. Problem polega na tym, że, jak pisze Heywood, wszystkie modele natury ludzkiej są normatywne, „stworzone na bazie założeń filozoficznych i moralnych, w związku z czym z zasady nie da się ich zweryfikować"4 . Niemożliwość definitywnego rozstrzygnięcia tej fundamentalnej kwestii stanowi tym samym zaczyn każdego sporu politycznego. To prowadzi nas do kwestii drugiej - tego, jak istotne jest badanie sfery świadomości politycznej, ideologii, doktryn, programów, które wprost lub implicite zawierają określone przekonania o naturze ludzkiej. Tego rodzaju badania nie są oczywiście niczym nowym, stanowią jeden z tradycyjnych obszarów refleksji nauk politycznych i mają bardzo obszerny dorobek merytoryczny i metodologiczny.

Odrębnym zagadnieniem pozostaje, na ile tego rodzaju rozważania obecne są w świadomości podmiotów kształtujących rzeczywistość polityczną. Jakkolwiek można wskazać na przestrzeni wieków wybitnych myślicieli i działaczy politycznych, których idee wpłynęły na tok procesów historycznych, można również założyć, że tego rodzaju rozbudowana i wysublimowana refleksja nie jest dominującą społecznie formą świadomości politycznej. Niemniej, jeżeli uznamy za trafne ustalenia teorii polityki, stwierdzające ścisłe związki pomiędzy świadomością i działaniem politycznym, znajdujące również uzasadnienie w psychologicznym twierdzeniu o wiedzy jako podstawowym regulatorze działania, to należy oczekiwać, że w przypadku każdego indywidualnego podmiotu polityki, bez względu na poziom politycznego wyrafinowania, stan wiedzy i posiadane zasoby intelektualne, tego rodzaju zależności dają się zaobserwować. Oznacza to, że również zwykły, statystyczny obywatel podejmuje działania i decyzje w oparciu o określone przekonania, choć nie muszą one przybierać formy uporządkowanych i skończonych systemów filozoficznych czy ideologiczno-doktrynalnych. Co więcej, wydaje się, że w epoce polityki masowej rozważania i dysputy elit intelektualnych i politycznych mają mniejsze znaczenie niż zdroworozsądkowe opinie i przekonania tzw. zwykłych ludzi. Mniej waży adekwatność wysublimowanych teorii filozoficznych czy antropologicznych, roz-

3 Jako przykład niech posłuży jedna z prac poświęconych ideologiom politycznym, w której pojęcie natury ludzkiej, jako uzasadnienie bądź wyjaśnienie określonych postulatów lub twierdzeń, występuje we wszystkich rozdziałach, z czego każdy poświęcony jest innej ideologii. Zob. R. Eccleshall et al., Political Ideologies. An Introduction, London-New York 2003.

4 A. Heywood, op. cit., s. 29. 
wijanych i dyskutowanych w wąskim kręgu specjalistów, niż apodyktyczność osobistych sądów i przekonań, których prawomocność ugruntowana jest w procesach społecznej walidacji. Dotyczy to również przekonań o naturze człowieka, jego potrzebach, dyspozycjach, przeznaczeniu czy istotowych dążeniach. Stawiam w związku z tym tezę, że tego rodzaju potoczne przekonania o naturze człowieka stanowią istotny element świadomościowych uwarunkowań zachowań i działań politycznych. Jako takie są wobec tego interesującym przedmiotem refleksji naukowej, któremu należy się uwaga, podobnie jak innym zjawiskom ze sfery świadomości politycznej. Co więcej, owe potoczne przekonania o naturze ludzkiej mają swoją strukturalną specyfikę, która - jak postaram się wykazać - uzasadnia ich terminologiczne wyodrębnienie ze sfery zjawisk świadomościowych. W tym celu proponuję pojęcie antropodoksy, czyli antropologii potocznej, na opisanie potocznych, zdroworozsądkowych przekonań o naturze człowieka, które $\mathrm{w}$ przypadku, gdy zostają powiązane $\mathrm{z}$ roszczeniami i dążeniami politycznymi, a więc odnoszącymi się do sfery relacji władzy, mogą zostać określone mianem antropodoksy politycznej, czyli potocznej antropologii polityki. Innymi słowy: mianem antropodoksy politycznej określimy taki zbiór potocznych przekonań na temat natury ludzkiej, które stanowią uzasadnienie i usprawiedliwienie określonych rozstrzygnięć i preferencji w zakresie stosunków władzy.

Proponowane pojęcie jest parafrazą terminu „antropologia”, przy czym jego drugi człon to grecka $\delta o ́ \xi \alpha$, oznaczająca mniemanie, złudne przekonanie, twierdzenie niewystarczająco uzasadnione, a przeto niemogące mieć statusu wiedzy pewnej i niepodważalnej. Wstępnie możemy więc rozumieć antropodoksę jako pewną formę wiedzy, ale wiedzy naiwnej, potocznej, subiektywnej, niezweryfikowanej, której przedmiotem jest człowiek. Należy tu podkreślić, że konstrukcja semantyczna tego pojęcia nie jest przypadkowa. Jej pierwszym źródłem teoretycznym, uzasadniającym użycie źródłosłowu anthropos, jest antropologia filozoficzna w jej klasycznej postaci (Max Scheler, Helmut Plessner, Arnold Gehlen), drugim natomiast, znajdującym wyraz w członie doksa, jest tzw. psychologia potoczna ${ }^{5}$.

\section{Antropodoksa jako kategoria teoriopolityczna}

Ponieważ antropodoksa polityczna została wstępnie określona jako pewna forma przedmiotowo określonej wiedzy, pozwala to ją umieścić w sferze zjawisk świadomościowych. Stanowią one bardzo istotny element teoriopolitycznej siatki pojęciowej z uwagi na bezpośrednie związki z działaniami politycznymi. Świadomość polityczna jest bowiem elementem wstępnym dla zachowań politycznych ${ }^{6}$ i możemy ją rozumieć jako subiektyw-

${ }^{5}$ Oba wymienione, źródłowe obszary refleksji zostaną przybliżone w dalszej części artykułu.

${ }^{6}$ Działania polityczne są jedną z form zachowań politycznych, wyróżnioną ze względu na kryterium świadomości, celowości i dowolności. Por. L. Sobkowiak, Działania polityczne. Teoria i praktyka, [w:] Marketing polityczny w teorii i praktyce, red. A.W. Jabłoński, L. Sobkowiak, Wrocław 2002, s. 15-21; S. Wróbel, Zachowanie i działanie polityczne, [w:] Wprowadzenie do nauki o państwie i prawie, red. B. Szmulik, M. Żmigrodzki, Lublin 2007, s. 265-286; A. Czajowski, Decydowanie w polityce, Wrocław 2013, s. 41-67; 
ne odzwierciedlenie rzeczywistości politycznej. Może ona przybierać formę potoczną, charakteryzującą się pewnym nieuporządkowaniem i spontanicznością, lub też postać usystematyzowanych ideologii i doktryn politycznych ${ }^{7}$. O ile druga $\mathrm{z}$ wymienionych tu form świadomości politycznej stanowi jeden z tradycyjnych obszarów refleksji politologicznej, o tyle namysł i próby kategorialnego uporządkowania i scharakteryzowania potocznych form świadomości politycznej wydają się rzadsze i bardziej zdawkowe.

Świadomość polityczną definiuje się ,jako całokształt poglądów, wiedzy, ocen, wartości, wzorów zachowań i postaw społeczeństwa, będących rezultatem wzajemnych

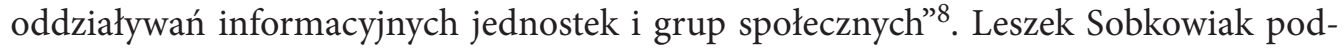
kreśla jej rolę jako czynnika silnie warunkującego funkcjonowanie podmiotów polityki i całego systemu politycznego. Jako jedna ze sfer świadomości społecznej, pełni dwie zasadnicze funkcje. Pierwsza $\mathrm{z}$ nich, poznawcza (orientacji), oznacza przypisywanie poszczególnym elementom otoczenia podmiotu (zbiorowego bądź indywidualnego) oraz jemu samemu określonych treści opisujących i wyjaśniających. Funkcja druga, praktyczna (regulacyjna), odnosi się natomiast do wiedzy o praktycznych sposobach działania w rzeczywistości społecznej w kierunku wywierania na nią wpływu ${ }^{9}$. Te dwie funkcje, choć analitycznie rozdzielone, należy traktować jako nierozerwalnie z sobą powiązane. Element behawioralny (funkcja praktyczno-regulacyjna) nie daje się bowiem logicznie odseparować od elementu kognitywnego (funkcja poznawczo-orientacyjna), w którym jest zakorzeniony. Trudno wyobrazić sobie wiedzę o praktycznym działaniu bez wiedzy o właściwościach poszczególnych elementów środowiska, w którym ono przebiega, czy projekt ukierunkowanego oddziaływania na rzeczywistość bez wiedzy o tym, jakie właściwości mają jej poszczególne elementy i jak będą odpowiadać na bodźce ze strony działającego podmiotu. Na ile wiedza ta poprawnie opisuje rzeczywistość i faktycznie zapewnia możliwość sprawczego i planowego oddziaływania, jest kwestią odrębną. Antropodoksa polityczna, jako zbiór twierdzeń odnoszących się do jednego z istotnych elementów środowiska każdego działania politycznego człowieka, jest więc jednym z elementów szerszej kategorii — świadomości politycznej. Element ten jest o tyle istotny, że ostatecznie człowiek zawsze pozostaje niezbywalnym substratem polityki, czy to jako jej przedmiot, czy to jako podmiot.

Struktura tak rozumianej świadomości politycznej składa się z trzech części: wiedzy politycznej, emocji ocen i wartości politycznych oraz wzorów zachowań ${ }^{10}$. W tym kontekście antropodoksa polityczna byłaby związana z poznawczą częścią świadomo-

M. Karwat, W. Malinowski, Działania polityczne jako składnik systemu praktyki społecznej, [w:] Elementy teorii polityki, red. K. Opałek, Warszawa 1989, s. 110-116.

7 Encyklopedia politologii, t. 1, red. W. Sokół, M. Żmigrodzki, Kraków 1999, s. 283.

8 Leksykon politologii, red. A. Antoszewski, R. Herbut, Wrocław 1997, s. 422.

9 L. Sobkowiak, Świadomość i socjalizacja polityczna, [w:] Studia z teorii polityki, red. A.W. Jabłoński, L. Sobkowiak, t. 1, Wrocław 1999, s. 155-156. Świadomość polityczna jest zdaniem tego autora jedną ze sfer świadomości społecznej, z której wyodrębniona zostaje według kryterium przedmiotowego. Z tej racji sądzić należy, że funkcje i właściwości świadomości społecznej jako kategorii szerszej odnoszą się również do jej podtypu — świadomości politycznej.

10 Ibidem, s. 157. 
ści politycznej (wiedzą polityczną), lokując się w jej warstwie potocznej, zakorzenionej w empirycznych, przeszłych doświadczeniach podmiotów, mającą charakter zdroworozsądkowy, intuicyjny, powierzchowny, nieusystematyzowany ${ }^{11}$. Jest to więc ta warstwa świadomości, w której w największym stopniu mamy do czynienia z kwestią zsubiektywizowanego ujęcia przez podmiot obiektywnych warunków działalności politycznej i samego siebie. Tadeusz Bodio dowodzi, że wiedza jest jednym z tych elementów, które obok wartości, norm i emocji stanowią podstawę działań w sferze politycznej ${ }^{12}$. To pozwala mówić mu o istnieniu ścisłego związku pomiędzy świadomością i działaniami, przejawiającego się w strukturalno-funkcjonalnych powiązaniach obu fenomenów.

Powiązania te uzewnętrzniają się między innymi w tym, że działanie jest uzależnione od stanu wiedzy o przedmiocie i warunkach działania, która z kolei jest wartościowana i oceniania przez pryzmat potrzeb i interesów podmiotu. Świadomość z jednej strony włącza się i warunkuje przebieg działania, z drugiej rozwija się i obiektywizuje w tych działaniach ${ }^{13}$.

Uwzględniając te związki i pamiętając, że antropodoksa polityczna jako potoczna wiedza o człowieku stanowi jeden z elementów świadomości politycznej, możemy stwierdzić, iż pełni względem działania funkcje regulacyjno-motywacyjne. Innymi słowy: wiedza antropodoksalna ukierunkowuje i energetyzuje interwencje w rzeczywistość polityczną podejmowane przez podmiot będący jej nosicielem. W tym względzie przypomina inne zjawisko ze sfery świadomości politycznej - ideologię, również będącą regulacyjno-motywacyjną przesłanką działania politycznego ${ }^{14}$. Ponieważ ideologia, jak twierdzi Heywood, zawiera jakąś koncepcję natury ludzkiej, to w zasadzie nic nie stałoby na przeszkodzie, by antropodoksę polityczną potraktować jako część ideologii, gdyby nie fakt, że stanowi ona jakościowo odmienną formę świadomości politycznej. Definiowana $w$ kategoriach opisowych ideologia rozumiana jest najczęściej jako rozwinięta, uporządkowana forma myśli politycznej, całokształt idei, poglądów na świat i życie społeczne, zbiór wartości i zasad postępowania, właściwy określonej grupie społecznej, klasie, ruchowi politycznemu czy partii ${ }^{15}$. Jakkolwiek składające się na ideologię przekonania charakteryzują się wysokim poziomem ogólności, to jednocześnie jest to system stosunkowo spójny, uporządkowany, stanowiący zorganizowaną całość. Antropodoksa natomiast została określona jako wiedza potoczna. To oznacza, że ma ona charakter mniej uporządkowany i usystematyzowany, słabiej wykrystalizowany, często fragmentaryczny i niekoniecznie spójny, ogólnie rzecz biorąc - mniej wyrafinowany ${ }^{16}$. Pod tym

11 Ibidem, s. 158.

12 T. Bodio, Świadomość a zachowania polityczne, Warszawa 1989, s. 84-85. Por. także A. Bodnar, Nauka o polityce. Podręcznik akademicki, Warszawa 1988, s. 170.

13 Ibidem, s. 161.

${ }^{14}$ K. Rudnicki, Wiedza i wartości działających podmiotów polityki, [w:] Elementy teorii polityki..., s. 159-162; W. Kostecki, Ideologia polityczna jako forma świadomości społecznej, [w:] Elementy teorii polityki..., s. 173; Leksykon politologii..., s. 124.

${ }^{15}$ Leksykon politologii..., s. 24; Encyklopedia politologii..., s. 125; International Encyclopedia of the Social \& Behavioral Science, t. 11, red. N.J. Smelser, P.B. Baltes, Amsterdam 2001, s. 7173; F. Ryszka, Wstęp do nauki o polityce. Uwagi metodologiczne, Warszawa-Poznań 1984, s. 102.

16 Ideologię od potocznej wiedzy politycznej odróżnia również Wacław Pluskiewicz, wskazując w przypadku tej pierwszej właśnie na uporządkowanie, spójność i trwałość jako cechy dystynktywne, odróżniają- 
względem należałoby więc potraktować ją raczej jako część składową pojęcia nadrzędnego względem ideologii - światopoglądu ${ }^{17}$, stanowiącego epistemologiczne i aksjologiczne podstawy ideologii, który nie musi cechować się spójnością i logicznością. Kategorię tę możemy definiować jako filozoficzny obraz świata, katalog humanistycznych ideałów, obraz całości środowiska społecznego danej grupy, a zarazem sąd o sensie życia jednostki, jej znaczeniu i przeznaczeniu. Światopogląd odnosi się do kwestii najbardziej ogólnych, zawiera pogląd na sprawy najbardziej fundamentalne i ostateczne, takie jak: sposób istnienia świata, jego poznawalność, zasadnicze kwestie aksjologiczne moralności i etyki, czy wreszcie los człowieka, jego miejsce w społeczeństwie i świecie, stosunek do egzystencji i śmierci, powstania życia, społeczeństwa, przyrody, Boga. Z jednej strony cechuje się zatem wysokim poziomem ogólności i abstrakcyjności, z drugiej zaś szerokim zakresem przedmiotowym ${ }^{18}$. W tym kontekście należy traktować wiedzę antropodoksalną jako wydzieloną przedmiotowo część światopoglądu odnoszącą się do natury człowieka, jego przyrodzonych dyspozycji, charakterystyki, istotowych dążeń i potrzeb, stanowiącą jeden z filarów ideologii.

\section{Antropo-}

Ponieważ antropologia filozoficzna została wskazana jako jedna z teoretycznych inspiracji dla pojęcia antropodoksy, uzasadnione wydaje się krótkie wprowadzenie, czym zajmuje się ów nurt refleksji filozoficznej. Należy jednak podkreślić, że inspirację stanowiły nie tyle same twierdzenia antropologii filozoficznej, ile raczej ich struktura, sposób ujmowania i opisu jej przedmiotu. Trzy kwestie są w tym kontekście szczególnie istotne. Pierwszym są jej ambicje syntezujące, dążenie do stworzenia ogólnej nauki o człowieku, zidentyfikowanie i opisanie pierwszej zasady ludzkiego bytu, wyjaśniającej całą różnorodność i złożoność jego obecności w świecie. Kwestią drugą jest diachroniczny i dynamiczny charakter bytu ludzkiego, ostatnią zaś normatywno-ewaluatywny potencjał twierdzeń, uwidaczniający się szczególnie w dorobku Arnolda Gehlena.

Czym wobec tego jest antropologia filozoficzna? Otóż można ją rozumieć dwojako. Z jednej strony jest ona pojmowana jako szczególny kierunek filozoficznej refleksji, charakteryzujący się uwrażliwieniem na problem człowieka, $z$ drugiej zaś jako odrębna szkoła filozoficzna, z własnym programem i zestawem pytań podstawowych. W tym ujęciu traktuje ona zagadnienie człowieka jako centralny moment światopoglądu filozoficznego, próbuje ustalić rolę i stanowisko człowieka w świecie i podejmuje próby opisania konstytucji istoty ludzkiej ${ }^{19}$. Cel ten realizuje za pomocą dwóch alternatywnych strategii. Pierwsza polega na wyjściu od obszernego materiału badań nauk szczegółowych, który

ce ją od potocznej wiedzy politycznej: idem, Świadomość polityczna - analiza strukturalna, Gliwice 1992, s. 66-69, za: L. Sobkowiak, Świadomość..., s. 159-160.

17 Por. A. Bodnar, op. cit., s. 272; Leksykon politologii..., s. 423; Encyklopedia politologii..., s. 125.

18 W. Kostecki, op. cit., s. 176; A. Bodnar, op. cit., s. 273; F. Ryszka, Nauka o polityce. Rozważania metodologiczne, Warszawa 1984, s. 175-176; Leksykon politologii..., s. 423.

19 R. Michalski, Homo defectus w kulturze późnej nowoczesności, Toruń 2013, s. 119-120. 
zostaje uogólniony w syntezie antropologicznej, druga zaś, abstrahując od nauk empirycznych, przyjmuje filozoficzny punkt wyjścia i próbuje ująć istotę człowieka poprzez interpretacje jego samorozumienia i samodoświadczenia ${ }^{20}$. Jakkolwiek więc antropologia nie jest i nigdy nie była jednolitym programem namysłu nad człowiekiem, to jednocześnie jej aspiracje syntezujące pozawalają na wyodrębnienie jej jako odrębnego nurtu refleksji filozoficznej. Antropologia „jako wiedza filozoficzna świadomie interesuje się naturą i istotą faktów antropologicznych, dąży do odkrycia tego, co w nich pierwsze i zasadnicze, i co jako takie wyjaśnia ich ukonstytuowanie się oraz własny ludzki sens" pisze Antoni Siemianowski ${ }^{21}$. Jest nauką o człowieku, która „przy pomocy wiedzy racjonalnej objaśnia jego istotę, cechy decydujące o tym, że dany byt nazywamy osobą ludzką"22. Ów syntezujący wątek odnaleźć można u klasyków tej tradycji intelektualnej.

Celem filozoficznej antropologii - pisze Max Scheler — jest dokładne pokazanie, jak z podstawowej struktury człowieka [...] wynikają jego wszystkie specyficzne monopole, osiągnięcia i dzieła: język, sumienie, narzędzia, broń, idee prawa i niesprawiedliwości, państwo, przywództwo, przedstawiające funkcje sztuk, mit, religia, nauka, dziejowość i uspołecznienie ${ }^{23}$.

Helmut Plessner, używając pojęcia antropologii uniwersalnej, pisze, iż jest to „nauka o istocie człowieka uwzględniająca wyraźnie wszystkie jego sposoby istnienia i formy przejawiania się"24. Zdaniem Arnolda Gehlena antropologia musi pozostawać zakorzeniona w naukach szczegółowych. Traktując człowieka jako przedmiot swych badań, jest nauką nadrzędną, „łączącą nauki o zakresach częściowych albo syntezującą problematykę czerpaną z nich wszystkich"25.

Powyżsi teoretycy dochodzą również do zbliżonych konkluzji odnośnie do tego, czym jest natura ludzka, co czyni byt ludzki szczególnym na tle innych bytów, jaka jest jego zasadnicza charakterystyka. Scheler określa ją mianem „otwartości na świat”, Plessner - „ekscentrycznej pozycjonalności”, Gehlen nazywa ją natomiast „ułomnością, naznaczeniem brakiem". Określenia te wskazują na

otwarty charakter ludzkiego sposobu istnienia, na fakt, że nie jest on do końca określony przyrodniczo, nie jest tylko wytworem natury, że przeciwnie — to właśnie jego „natura” sprawia, że jest mu potrzebna druga „natura”, natura społeczna, którą tworzy sam w swej historii ${ }^{26}$.

Owa potrzeba drugiej natury jest tym, co napędza człowieka, co sprawia, że nie jest on istotą skończoną, lecz stającą się, aktualizującą się w toku swojej aktywności i w swoich wytworach, stanowiących odpowiedź na ową pierwszą zasadę ludzkiej kondycji. Tu właśnie ujawnia się ów diachroniczno-dynamiczny charakter bytu ludzkiego, który na-

20 E. Coreth, Czym jest antropologia filozoficzna?, „Studia Filozoficzne” 1983, nr 4, s. 175.

21 A. Siemianowski, Antropologia filozoficzna, Gniezno 1996, s. 42.

22 C. Valverde, Antropologia filozoficzna, Poznań 1998, s. 11.

${ }^{23}$ M. Scheler, Pisma z antropologii filozoficznej i teorii wiedzy, Warszawa 1987, s. 142.

${ }^{24} \mathrm{H}$. Plessner, Władza a natura ludzka. Esej o antropologii światopoglądu historycznego, Warszawa 1994, s. 14.

25 A. Gehlen, W kreggu antropologii i psychologii społecznej, Warszawa 2001, s. 75-76.

26 Z. Krasnodębski, Ekscentryczność człowieka. O idei antropologii filozoficznej, [w:] H. Plessner, Spór o conditio humana, Warszawa 1988, s. 19. 
znaczony niedostatkiem dąży do spełnienia ${ }^{27}$, istoty aktywnej, twórczo przekształcającej swoje środowisko naturalne $\mathrm{w}$ sferę kultury ${ }^{28}$. To czyni antropologię filozoficzną nauką o metafizycznym pochodzeniu człowieka, ,jego filozoficznym, psychicznym i duchowym początku w świecie; o siłach i mocach, które nim poruszają i które on uruchamia; o podstawowych kierunkach i prawach jego rozwoju biologicznego, psychicznego, historyczno-duchowego i społecznego" 29 . Te słowa Schelera pozwalają spojrzeć na antropologię jako szczególną opowieść o istocie, która się rozwija, jest w trakcie procesu stawania się, konfrontując się w nim z pewnymi siłami i okolicznościami oraz ujawniając swoją moc sprawczą. Mówiąc prościej, antropologia filozoficzna jawi się w tej perspektywie jako opowieść o tym, jaki jest człowiek i jak to determinuje jego los, jak ukierunkowuje i warunkuje jego dążenia i działania. Możemy ją rozumieć jako próbę stworzenia uniwersalnej i syntezującej narracji o filogenetycznych dziejach człowieka.

U Gehlena tezy antropologiczne prowadzą ponadto do bardzo wyrazistych konstatacji politycznych. Człowiek, istota ułomna, przytłoczony nadmiarem bodźców i zagrażającą mu nadwyżką energii, potrzebuje swoistych wsporników, sił odciążających i stabilizujących oraz umożliwiających rozwiązywanie zadań decydujących o życiu. Tych upatruje w różnych systemach kierujących: religii, światopoglądzie, a przede wszystkim w instytucjach, które stanowią protezę wobec słabości spowodowanej brakiem instynktowego wyposażenia, będąc elementem kluczowym dla przetrwania człowieka ${ }^{30}$. W ten sposób Gehlen, potępiający krytykę status quo, dążenia emancypacyjne oraz tendencje demokratyzujące życie polityczne, postrzegany jest jako orędownik konserwatywnego systemu wartości ${ }^{31}$, a twierdzenia o charakterze antropologicznym stają się ostatecznie kryterium oceny rzeczywistości politycznej, uzasadniając określony jej stan jako bardziej niż inny odpowiadający naturze ludzkiej. Tym samym do antropologii jako opowieści o dziejach zmagań człowieka z sytuacją, w której stawia go własna natura, zostaje dodany wątek normatywny, mówiący o tym, jaki stan rzeczy jest pożądany jako zgodny z ludzką naturą. Antropologia filozoficzna, szczególnie w wersji Gehlenowskiej, rozstrzygając o tym, jaki jest człowiek i jakie w związku z tym stoją przed nim cele, jakie ma potrzeby i motywacje, tworzy grunt do odpowiedzi na pytanie o to, jaki porządek polityczny jest w związku z tym najbardziej dla niego odpowiedni.

Jakkolwiek można z dużą dozą prawdopodobieństwa stwierdzić, że szczegółowe twierdzenia antropologii Schelera, Plessnera czy Gehlena nie są bliżej znane dominującej

27 H. Plessner, Władza..., s. 77.

28 A. Gehlen, op. cit., s. 35-38, 80-82.

29 M. Scheler, op. cit., s. 150.

30 A. Gehlen, op. cit., s. 111-123; W. Rügemer, Główne dzieło Gehlena „Der Mensch“ i mit antropologii empiryczno-biologicznej, „Studia Filozoficzne” 1983, nr 8-9, s. 257-263; S. Horonziak, Institutions as the forces of stabilizing state. Contemporary look at the Arnold Gehlen's theory of institutions, „Political Dialogues” 2015, nr 18, s. 115-118.

31 R. Michalski, op. cit., s. 390; K.-S. Rehberg, Antropologia działania i teoria porządku Arnolda Gehlena, [w:] Konserwatyzm. Projekt teoretyczny, red. B. Markiewicz, Warszawa 1985, s. 73-84; P. Kimla, Arnold Gehlen w obronie instytucji i klasycznych zadań władzy i instytucji państwa, „Państwo i Społeczeństwo” 2005, nr 1, s. 48-49. 
większości dowolnego społeczeństwa, to widoczny w niej sposób rozumowania, logika wywodu, obecne są w myśleniu potocznym, w codziennych ludzkich próbach ustosunkowania się do zjawisk i procesów społeczno-politycznych. W myśleniu potocznym często bowiem posługujemy się schematem rozumowania, który ujawnia się w antropologii filozoficznej, uzasadniając np. swoje preferencje czy decyzje polityczne odwołaniem się do rzekomo oczywistej natury człowieka, rozstrzygając kategorycznie o jego potrzebach i najlepszych sposobach ich zaspokojenia. Co więcej, uzasadnienie to przyjmuje strukturę narracyjną, tworzy opowieść, w której człowiek jawi się jako podmiot dążący do określonych celów, napędzany określonymi siłami, borykający się z trudnościami wynikającymi z okoliczności zewnętrznych czy z samej jego natury i wymagający w związku z tym określonych rozwiązań instytucjonalno-ustrojowych.

\section{-doksa}

Dotychczasowe rozważania pozwoliły na zdefiniowanie antropodoksy jako pewnej formy wiedzy i umieszczenie jej w sferze zjawisk świadomościowych, w których zakorzenione jest działanie polityczne. Określony został jej zakres przedmiotowy, doprecyzowania wymaga jeszcze kwestia właściwości tej formy wiedzy, czym jest w istocie i jakie konsekwencje teoretyczne niesie z sobą jej wstępnie charakteryzowana dotychczas „potoczność”.

Problem z kategorią potoczności polega jednak na tym, że jak wiele innych pojęć, od dawna obecnych w różnych dyscyplinach wiedzy o człowieku, jest ono niejednoznaczne.

„Potoczność”, „myślenie potoczne”, „życie codzienne”, „świat przeżywany” to pojęcia raczej niejednoznaczne, definiowane różnie przez używających je badaczy, które trwale przeniknęły do języka nauk humanistycznych, szczególnie etnologii, socjologii, filozofii kultury. Są to dziś pojęcia uznane za niezwykle ważne, wyznaczające teren badań i kierunek interpretacji ludzkiego działania

- pisze Aldona Jawłowska ${ }^{32}$. Ponieważ omówienie licznych tropów teoretycznych ${ }^{33}$ przekracza zakres niniejszego artykułu, poprzestanę jedynie na deklaracji co do sposobu rozumienia tej kategorii przyjętego na potrzeby artykułu.

Antropodoksa zaliczona została wcześniej do zjawisk świadomościowych, perspektywa psychologiczna wydaje się więc szczególnie predysponowana do charakterystyki wiedzy antropodoksalnej. Wiedzę potoczną, potoczność jako cechę wiedzy antropodoksalnej, będę rozumiał za Jerzym Trzebińskim jako „wiedzę ukształtowaną w drodze naturalnego rozwoju, tzn. w drodze naturalnych kontaktów jednostki z obiektem wiedzy lub z innymi osobami, które przekazują lub negocjują z poznającym treść wiedzy"34. To, co w kategoriach teoriopolitycznych określone zostało wcześniej jako strukturalno-funkcjonalne powiązania pomiędzy świadomością i działaniem, ma swoją analogię

32 A. Jawłowska, Wstęp, [w:] Kategoria potoczności. Źródła filozoficzne i zastosowania teoretyczne, red. eadem, Warszawa 1991, s. 5-6.

33 Omówienie obszernej tradycji stosowania kategorii „wiedzy potocznej” w filozofii, socjologii i antropologii zob. A. Malewska-Szałygin, Zarys tradycji stosowania pojęcia „wiedza potoczna”, „Etnografia Polska” 1995, nr 1-2, s. 51-63.

34 J. Trzebiński, Narracyjne formy wiedzy potocznej, Poznań 1991, s. 9. 
w terminologii psychologicznej. Z perspektywy psychologicznej wiedza jest bowiem najważniejszym regulatorem działania.

Ponieważ jednostka kieruje się w swoich działaniach przede wszystkim własną wiedzą o świecie, a niekoniecznie rzeczywistym stanem świata, analiza budowy i funkcjonowania jednostkowej wiedzy społecznej ma podstawowe znaczenie dla wyjaśniania i przewidywania społecznych zachowań jednostki

- pisze Bogdan Wojciszke ${ }^{35}$. Człowiek jako istota sprawcza „podejmuje działania celowe, których przebieg bywa regulowany przez wiedzę zakodowaną w umyśle i informacje płynące ze środowiska” - stwierdza z kolei Jerzy Kozielecki ${ }^{36}$. W prezentowanym przez tych badaczy paradygmacie poznawczym wiedza ma charakter konstrukcyjny, przybiera formę interpretowania danych napływających z zewnątrz i generowanych przez ludzki umys $^{37}$. To oznacza, że podmiotowa wiedza społeczna nie jest prostym odzwierciedleniem rzeczywistości, lecz jedynie jego psychiczną reprezentacją ${ }^{38}$, będącą rezultatem przetwarzania bodźca informacyjnego przez aktywny w procesie poznawczym umysł i jego struktury. W rezultacie każda podmiotowa wiedza o dowolnym fragmencie rzeczywistości ma charakter interpretacji.

Świat społeczny - piszą Bogdan Wojciszke i Dariusz Doliński — jest światem interpretowanym — znaczenie sytuacji i zachowań społecznych nie są z góry i „obiektywnie” dane, lecz w dużym stopniu stanowią skutek interpretacji dokonywanych na bieżąco przez uczestniczących w nich ludzi ${ }^{39}$.

W tej perspektywie to, co wiemy, jest wynikiem subiektywnego doświadczenia rzeczywistości. Ów subiektywno-intepretacyjny charakter podmiotowej wiedzy zawdzię-

35 B. Wojciszke, Teoria schematów społecznych. Struktura i funkcjonowanie jednostkowej wiedzy o otoczeniu społecznym, Wrocław 1986, s. 7.

36 J. Kozielecki, Koncepcje psychologiczne człowieka, Warszawa 2000, s. 213.

37 W tym kontekście interpretacja jest „pewną czynnością lub zespołem czynności podmiotu spostrzegającego i interpretującego. Najogólniej można powiedzieć, że czynność ta polega na wprowadzeniu do postrzeżenia wyników nie wyznaczonych przez fizyczne właściwości przedmiotu, ani organów zmysłowych, przy czym, to, co jest wprowadzone, wynika z zajęcia pewnej postawy psychicznej względem postrzeganego podmiotu". Zob. J. Bobryk, Teoretyczny punkt wyjścia: czynności spostrzegania i interpretowania, wytwory tych czynności, dyspozycje psychiczne je determinujace, [w:] Percepcja i interpretacja społecznej i politycznej sytuacji w Polsce, red. I. Kurcz, J. Bobryk, Warszawa 1997, s. 53. Badacze i teoretycy nurtu poznawczego w psychologii stoją na gruncie konstruktywistycznej koncepcji poznania, co znajduje swój wyraz już w pracy uznawanej za pierwszą, w której nastąpiło pełne samookreślenie tego nurtu (U. Neisser, Cognitive Psychology, New York 1967). Nurt ten kładzie szczególny nacisk na proces myślenia, sposób, w jaki ludzie dochodzą do rozumienia rzeczywistości, jak ludzki umysł przyswaja, przetwarza informacje i w jaki sposób są one reprezentowane w umyśle (R.S. Feldman, Social Psychology. Theories, Research and Aplications, New York 1985, s. 14-15). O genezie i głównych założeniach paradygmatu poznawczego w psychologii więcej w: I. Kurcz, Psychologia poznawcza, [w:] Psychologia a semiotyka: pojęcia i zagadnienia, red. eadem, Warszawa 1993, s. 9-24; W. Łukaszewski, Psychologiczne koncepcje człowieka, [w:] Psychologia. Podręcznik akademicki, red. J. Strelau, t. 2, Gdańsk 2000, s. 79-82; Psychologia poznawcza, red. E. Nęcka, Warszawa 1997; J. Kozielecki, op. cit., s. 167-235.

$38 \mathrm{Na}$ temat znaczenia terminu „reprezentacja”, jednego z charakterystycznych dla nurtu poznawczego, szerzej w: K. Najder, Reprezentacja poznawcza we współczesnej psychologii, [w:] Psychologia a semiotyka: pojęcia i zagadnienia..., s. 142-150.

39 B. Wojciszke, D. Doliński, Psychologia społeczna, [w:] Psychologia. Podręcznik akademicki, red. D. Doliński, J. Strelau, t. 2, Gdańsk 2008, s. 295. 
czamy schematom poznawczym, podstawowym strukturom poznawczym zawierającym wiedzę jednostki o rzeczywistości ${ }^{40}$. Streszczając powyższy wywód, możemy powiedzieć, że w procesie poznania rzeczywistości tworzymy wiedzę, która ma charakter zbioru psychicznych reprezentacji, będących rezultatem interpretacji bodźców informacyjnych przez metabolizujący je ludzki umysł. Ludzkie działania i zachowania są więc w istocie reakcją na tak zbudowane, subiektywne wyobrażenia o świecie.

Niezwykle ważnym, jeśli nie najważniejszym, elementem tego świata jest człowiek, a zatem podmiotowa wiedza na temat ludzi stanowi istotny przedmiotowy wycinek całej wiedzy jednostki. Zdawał sobie z tego sprawę Fritz Heider, którego uznaje się za prekursora psychologicznej refleksji nad wiedzą potoczną, jaką jednostki wytwarzają na temat innych ludzi. Przedmiot swych rozważań określił mianem psychologii zdroworozsądkowej lub naiwnej (common-sense psychology, naive psychology), podkreślając jej funkcję regulacyjną względem zachowań jednostki.

W życiu codziennym - stwierdza Heider - tworzymy wyobrażenia o innych ludziach i sytuacjach społecznych. Interpretujemy zachowania ludzi i przewidujemy, jak zachowają się w określonych okolicznościach. Choć wyobrażenia te zwykle nie są werbalizowane, to często pozostają trafne.

W tym sensie możemy mówić o

„psychologii naiwnej”, dostarczającej reguł używanych przez nas do budowy obrazu środowiska społecznego i kierującej naszymi reakcjami względem niego. Dlatego też wyjaśnienie zachowania musi uwzględniać zdroworozsądkową psychologię, bez względu na to, czy jej założenia i zasady dają się naukowo uprawomocnićc ${ }^{41}$.

Innymi słowy: psychologia naiwna, zwana również potoczną, to system zdroworozsądkowych przekonań na temat funkcjonowania ludzkiej psychiki, pozwalający przewidywać z pewną trafnością zachowania innych jednostek. Jest to umysłowa reprezentacja, poznawczy konstrukt obiektu „psychika człowieka”, wytwarzany przez jednostkę w toku codziennego życia i stanowiący część jej potocznej wiedzy o rzeczywistości. „Według najbardziej ogólnej i najmniej zobowiązującej teoretycznie definicji psychologia potoczna to opisywanie i wyjaśnianie zachowań praktykowane przez ludzi w codziennym życiu" ${ }^{2}$. Wiesław Łukaszewski z kolei pisze w tym kontekście o „systemie przekonań dotyczących natury ludzkiej oraz natury świata, w jakim żyjemy”, które kształtowane są od wczesnego dzieciństwa ${ }^{43}$. Człowiek jest bowiem, jak to określa Arkadiusz Białek,

40 Brak tutaj miejsca na pogłębioną prezentację zagadnienia schematów poznawczych. Czytelnik zainteresowany tym tematem znajdzie jego syntetyczne omówienie w przytaczanej już wcześniej pracy Wojciszke, ale również w: J. Trzebiński, Rola schematów poznawczych w zachowaniach społecznych, [w:] Psychologia spostrzegania społecznego, red. M. Lewicka, Warszawa 1985; M. Lewicka, B. Wojciszke, Wiedza jednostki i sady o świecie społecznym, [w:] Psychologia. Podręcznik akademicki, red. J. Strelau, t. 3, Gdańsk 2000, s. 27-44.

${ }^{41}$ F. Heider, The Psychology of Interpersonal Relations, New York-London 1964, s. 5. Cytuję za trzecim wydaniem pracy opublikowanej oryginalnie w $1958 \mathrm{r}$.

42 T. Grzegorek, Czy jeszcze jest psychologia potoczna?, „Studia Psychologiczne” 2011, nr 49, s. 49.

43 W. Łukaszewski, Psychologia podzielona, „Nauka” 2011, nr 4, s. 10. Nie jest to jednak jedyny sposób rozumienia terminu „psychologia potoczna”. W literaturze funkcjonuje bowiem jeszcze pojęcie „czytanie umysłów" (mindreading), obecne zwłaszcza w filozofii umysłu i kognitywistyce. Ten terminologiczny pluralizm wiąże się z różnymi sensami, jakie przypisuje się obecnie terminowi „psychologia potoczna”, z różnymi aspektami badań nad tym zjawiskiem. Termin „czytanie umysłów” zarezerwowany jest na określenie pew- 
swoistym homo psychologicus, istotą naturalnie uwrażliwioną na stany mentalne innych osób, ich emocje, nastroje, próby rozpoznania ich potrzeb i wyjaśniania na ich podstawie zachowann ${ }^{44}$. Zdaniem Jerome’a Brunera psychologia potoczna jest czymś, czego się uczymy, nabywamy w procesie socjalizacji, tak jak uczymy się języka i kultury, w której żyjemy ${ }^{45}$.

Praca Heidera dała asumpt do rozwoju, dziś już obszernej, tradycji badań nad tzw. ukrytymi teoriami osobowości czy procesami atrybucji ${ }^{46}$. Te pierwsze pozwalają na podstawie skąpego zbioru informacji tworzyć bardziej złożony obraz dyspozycji i cech człowieka $^{47}$, drugie natomiast opisują sposoby i reguły wnioskowania o przyczynowości ${ }^{48}$. Potoczne przekonania o naturze świata, naturze ludzkiej, funkcjonowaniu umysłu są w kontekście analizy aktywności politycznej jednostki o tyle ważne, że ich poznanie „jest kluczem do zrozumienia subiektywności i specyfiki indywidualnego poznania. Coraz częściej traktuje się je jako filtr percepcji, znajdujący się najbliżej zachowania" ${ }^{4}$. Koncepcje te mają jednak swoją specyfikę, jest to wiedza szczególnego rodzaju. W porównaniu do takich konstruktów, jak ideologia, doktryna czy program, charakteryzują się one znacznie niższym poziomem spójności, wyrafinowania czy uporządkowania. Są ponadto silnie nasycone wartościowaniem, składają się zazwyczaj z niewielkiej liczby twierdzeń, nie są spójne logicznie, bywają formułowane ad hoc, w zależności od po-

nego zestawu umiejętności poznawczych człowieka, pozwalających mu przewidywać i wyjaśniać ludzkie zachowanie. Natomiast termin „psychologia potoczna” oznacza zbiór społecznie podzielanych truizmów, frazesów i potocznych twierdzeń na temat funkcjonowania psychiki człowieka, formułowanych przez nieprofesjonalistów w toku codziennych interakcji z innymi ludźmi. Na potrzeby niniejszego artykułu odwołuję się do tego właśnie znaczenia. Por.: S.P. Stich, S. Nichols, Folk Psychology, [w:] The Blackwell Guide to Philosophy of Mind, red. S.P. Stich, T.A. Warfiled, Malden 2003, s. 238-241; I. Ravenscroft, Folk Psychology as a Theory, https://plato.stanford.edu/archives/fall2010/entries/folkpsych-theory/\#P (dostęp: 28 lutego 2017).

44 A. Białek, Patrz gdzie patrzę. Psychologiczne aspekty podejmowania cudzej perspektywy, Kraków 2010, s. 30 .

45 J. Bruner, The Acts of Meaning, Cambridge-London, 2002, s. 35. Jakkolwiek więc psychologia potoczna jest wiedzą jednostkową, to nie funkcjonuje ona w izolacji od kontekstu społecznego, w którym jest formułowana. Należy ją przeto rozpatrywać jako wiedzę do pewnego stopnia tworzoną kolektywnie i w takiż sposób weryfikowaną. Dostrzega to również Garth Fletcher, określając jako zdroworozsądkowe to, co stanowi zbiór przekonań o świecie, powszechnie żywionych w danej grupie kulturowej: idem, Psychologia a zdrowy rozsądek, „Nowiny Psychologiczne” 1985, nr 9-10, s. 5. Ten aspekt wiedzy potocznej dostrzega też Harold Garfinkel, jeden z twórców etnometodologii, który pisze, że określone twierdzenie staje się elementem wiedzy potocznej, kiedy „użycie go jako właściwej podstawy wnioskowania i działania jest dla użytkownika warunkiem uzyskania statusu uznanego członka społeczności”. Wiedza potoczna jest więc czymś, czym posługuje się jednostka, lecz uprawomocnia się w procesie społecznej interakcji: idem, Aspekt problemu potocznej wiedzy o strukturach społecznych, [w:] Fenomenologia i socjologia. Zbiór tekstów, red. Z. Krasnodębski, Warszawa 1989, s. 355.

${ }^{46}$ K. Lachowicz-Tabaczek, Potoczne koncepcje świata i natury ludzkiej. Ich wplyw na poznanie i zachowanie, Gdańsk 2004, s. 17-18.

47 P. Lewicki, Zjawisko „ukrytej teorii osobowości” w procesie spostrzegania społecznego, [w:] Psychologia spostrzegania społecznego..., s. 145-174.

48 M. Kofta, Procesy atrybucji w spostrzeganiu społecznym, [w:] Psychologia spostrzegania społecznego..., s. $175-216$.

49 K. Lachowicz-Tabaczek, op. cit., s. 70. 
trzeb i interesów podmiotu. Jednocześnie są bardzo kategoryczne, wręcz dogmatyczne, cechują się wysokim poziomem subiektywnej pewności, traktowane są jako a priori prawdziwe i niewymagające dowodu, mają charakter dymensjonalny, przybierając najczęściej postać dwubiegunowej alternatywy (człowiek jest: dobry/zły, egoistyczny/ altruistyczny itp.). Czasem ograniczają się do pojedynczych przekonań, niekiedy tworzą ich system, bywają luźnym zbiorem, bardziej wiązką twierdzeń niż spójną syntezą. Różnią się również swoim zakresem przedmiotowym. Opisują atrybuty różnych grup społecznych, czasem jedynie wybrany aspekt rzeczywistości, bądź stanowią o ogólnych, uniwersalnych ludzkich właściwościach ${ }^{50}$. Pełnią też rozliczne funkcje, m.in. objaśniają rzeczywistość, czyniąc ją zrozumiałą dla jednostki, pomagają w tworzeniu więzi społecznych, zyskiwaniu aprobaty grupy, budowie zbiorowej tożsamości, komunikacji oraz, co szczególnie istotne w kontekście prowadzonych tu rozważań, motywują działanie, jak również wpływają na tworzenie innych reprezentacji, jako swoiste metastruktury czy struktury prapojęciowe ${ }^{51}$. Ta ostatnia właściwość oznacza, że są niejako centralnie usytuowane w systemie wiedzy potocznej, a na ich bazie tworzone są inne bardziej złożone i konkretne konstrukty rzeczywistości.

Teza, jaką stawiam, stanowi o tym, że na podobnej zasadzie jak zdroworozsądkową wiedzę psychologiczną ludzie konstruują również zdroworozsądkową wiedzę antropologiczną. W drodze codziennych interakcji, poprzez praktyki dyskursywne, nabywają pewnych przekonań, tworzą wyobrażenia o tym, czym jest człowiek, jakie są jego cechy dystynktywne, skąd pochodzi i dokąd zmierza, jaka jest jego fundamentalna charakterystyka, uniwersalne dążenia, miejsce i sens bycia w świecie. Wiedza ta pełni analogiczne do wymienionych wyżej funkcje psychologii potocznej i posiada strukturę podobną do wywodu antropologii filozoficznej. Jej polityczny wymiar ujawnia się np. wtedy, gdy zdroworozsądkowe generalizacje, jak twierdzenie o tym, że „ludzie potrzebują silnej władzy” albo że „ludzie to egoiści”, stanowią uzasadnienie wsparcia określonych projektów politycznych. W porównaniu z psychologią potoczną nieco inny będzie jednak przedmiot tej wiedzy. Wiedza antropodoksalna nie dotyczyłaby więc wyobrażeń w psychicznej sferze funkcjonowania człowieka, lecz odnosiłaby się do egzystencjalnego wymiaru człowieczeństwa, kwestii transcendentalnych, wykraczających poza sferę empirycznego doświadczenia i fizycznego bytowania.

50 W. Łukaszewski, Wielkie pytania psychologii, Sopot 2015, s. 44; W. Łukaszewski, Psychologiczne koncepcje człowieka..., s. 87-88; W. Łukaszewski, Psychologia podzielona..., s. 10; K. Lachowicz-Tabaczek, op. cit., s. 72 .

51 W. Łukaszewski, Wielkie pytania psychologii..., s. 45; idem, Psychologiczne koncepcje człowieka..., s. 88-89; K. Lachowicz-Tabaczek, op. cit., s. 73-81; eadem, Przekonania o naturze ludzkiej jako element stylu regulacji zachowania, „Studia Psychologiczne” 2002, nr 2, s. 67-86; W. Łukaszewski, B. Weigl, Stereotyp stereotypu czy prywatna koncepcja natury ludzkiej?, [w:] Stereotypy i uprzedzenia. Uwarunkowania psychologiczne i kulturowe, red. M. Kofta, A. Jasińska-Kania, Warszawa 2001, s. 57-58. 


\section{Natura człowieka jako przedmiot myślenia politycznego}

Wiedza antropodoksalna, która w świetle rozważań teoriopolitycznych stanowi element świadomościowych uwarunkowań działania, stanowić będzie siłą rzeczy jeden z elementów myślenia politycznego. Jakkolwiek to ostatnie pojęcie nie jest precyzyjne, a jego granice są dość płynne i uwarunkowane kontekstowo, to w przybliżeniu określić nim możemy wszelkie poznawcze operowanie ideami, obrazami, symbolami, słowami, pojęciami czy przekonaniami. Myślenie polityczne będzie w tym ujęciu oznaczało całość procesów myślowych odnoszących się do polityki, czy szerzej - do sfery społecznej, których przejawami są różnego rodzaju sądy poznawcze (diagnostyczne, wyjaśniające, prognostyczne, oceniające, normatywne), stanowiące przedmiot badań psychologii polityki ${ }^{52}$. Opisane wyżej właściwości wiedzy antropodoksalnej pozwalają traktować ją jako ten element wiedzy, który w psychologii polityki za Reykowskim możemy określić mianem ogólnych założeń światopoglądowych.

Pewne elementy systemu wiedzy stanowią fundament, na którym budowane są wszelkie inne pojęcia i sądy. Są to przekonania o naturze człowieka i życia społecznego i o zasadach, na których świat społeczny powinien być budowany. Zasady te są traktowane jako prawdy oczywiste. Definiują one to, co jednostka uważa za obiektywnie prawdziwe, bezwarunkowo słuszne, do czego ma osobisty stosunek. Na ich podstawie człowiek odczytuje znaczenia zjawisk, z którymi się spotyka ${ }^{53}$.

Mają one charakter centralny, wokół nich ogniskują się i organizują przekonania i wiedza odnośnie do innych, bardziej konkretnych kwestii.

\section{Ogólne dyrektywy metodologiczne}

Dotychczas antropodoksa została określona jako przedmiotowo wyróżniony składnik wiedzy potocznej o charakterze narracyjnym. Dwie kwestie wymagają w tej chwili doprecyzowania - czym jest narracyjność oraz jak wyglądają jej związki z myśleniem potocznym.

Ponieważ kategoria narracyjności jest tutaj jedynie terminem pomocniczym, pomijam jego szczegółowe omówienie, które z racji genezy, wieloznaczności i interdyscyplinarności jest zagadnieniem niezwykle obszernym ${ }^{54}$. Poprzestanę jedynie na zadeklarowaniu stanowiska teoretycznego przyjętego na potrzeby niniejszego artykułu. Otóż

52 K. Skarżyńska, Człowiek a polityka. Zarys psychologii politycznej, Warszawa 2005, s. 25; J. Reykowski, Myślenie polityczne, [w:] Podstawy psychologii politycznej, red. K. Skarżyńska, Poznań 2002, s. 110-111.

53 Ibidem, s. 118.

${ }^{54}$ Kategoria narracyjności, wywodząca się z teorii literatury, obecna jest także w refleksji filozoficznej, badaniach nad tożsamością, w metodologii historii, socjologii, psychologii i psychoterapii, antropologii, językoznawstwie i semiotyce, a nawet w marketingu i zarządzaniu. Konceptualizowana jest zazwyczaj na gruncie strukturalizmu, choć niektóre jej ujęcia zakorzenione są w fenomenologii i hermeneutyce. Najbardziej chyba wszechstronne wprowadzenie do zagadnienia (choć niepokrywające wszystkich wymienionych wyżej obszarów refleksji naukowej) odnajdzie czytelnik w: D.E. Polkinghorne, Narrative Knowing and the Human Science, Albany 1988. 
narracyjność rozumiana będzie tutaj w sposób charakterystyczny dla psychologii narracyjnej - jako uniwersalna cecha ludzkiego myślenia, sposób porządkowania bodźców przez ludzki umysł i tworzenia ich reprezentacji mającej strukturę opowieści. Podstawowymi strukturami poznawczymi, zawierającymi uogólnioną wiedzę jednostki o otaczającej ją rzeczywistości, są schematy poznawcze. Możemy zdefiniować je jako

posiadaną przez podmiot wiedzę na temat określonego wycinka rzeczywistości, [...] semantyczną reprezentację określonego rodzaju treści. [...] zawiera ona nie wszystkie wiadomości podmiotu dotyczące danego fragmentu rzeczywistości, lecz jedynie wiedzę uogólnioną, wyabstrahowaną z konkretnych doświadczeń ${ }^{55}$.

Jednym z rodzajów schematów poznawczych są tzw. schematy narracyjne, w których wiedza organizowana jest w kategoriach aktora, celu oraz warunków i środków jego realizacji. Ich podstawowa, uniwersalna struktura opowiada o bohaterze $\mathrm{z}$ określonymi intencjami, napotykającym trudności, które w toku zdarzeń zostają bądź nie zostają przezwyciężone. Schemat ten modeluje więc bohaterów, żywione przez nich wartości i intencje, plany ich realizacji oraz warunki i szanse przezwyciężenia napotykanych trudności. Jest to również podstawowy schemat reprezentujący świat ludzi i bytów antropomorficznych ${ }^{56}$.

Narracyjność jest nie tylko uniwersalnym, ale wydaje się być również najbardziej naturalnym sposobem ludzkiego myślenia ${ }^{57}$. Tymczasem myślenie potoczne zostało opisane wyżej jako nieuporządkowane, fragmentaryczne, niespójne itd. Problematyczne wydaje się więc doszukiwanie się w myśleniu potocznym strukturalnego uporządkowania, charakteryzującego schematy narracyjne. Odnosząc się do tej kwestii, pragnę zwrócić uwagę na spostrzeżenia dwóch badaczy.

Wspominane już ukryte teorie osobowości (UTO) to wyobrażenie o związkach pomiędzy poszczególnymi cechami człowieka, które pozwalają na podstawie obecności określonych cech (psychicznych, społecznych, fizycznych, intelektualnych) wnioskować o istnieniu innych. Jest to więc naiwna teoria opisująca relację współwystępowania, korelacji cech, pozwalająca na podstawie stosunkowo małej ilości informacji o danej jednostce wytworzyć całkiem złożone jej wyobrażenie. Badania Trzebińskiego dowodzą jednak, że UTO mają budowę skryptową ${ }^{58}$. Nie tylko opisują korelacje cech czy grup cech, lecz charakterystyki te zostają także powiązane z celami podmiotów

55 B. Wojciszke, op. cit., s. 16.

56 J. Trzebiński, Narracyjne konstruowanie rzeczywistości, [w:] Narracja jako sposób rozumienia świata, red. idem, Gdańsk 2002, s. 23-26; idem, Narracyjne formy wiedzy potocznej..., s. 25-33.

57 Jerome Bruner, którego uznaje się za jednego z twórców psychologii narracyjnej, twierdzi, że narracyjny sposób poznawania świata charakteryzuje się, w przeciwieństwie do opartego na logice, abstrakcji i uogólnieniu trybu paradygmatycznego, podobieństwem poznawanych aktów do życia (lifelikness). Generuje on wyjaśnienia $\mathrm{w}$ formie atrakcyjnych historii, wiarygodnie brzmiących i wciągających (choć niekoniecznie trafnych) fabuł, zawierających konstrukty związków pomiędzy zdarzeniami: idem, Actual Minds, Possible Worlds, Cambridge-London 1986, s. 12-13. Jest to niejako naturalne nastawienie poznawcze człowieka, którego celem jest zrozumienie jednostkowego doświadczenia, odkrycie jego sensu, interpretacja i zrozumienie.

58 Skrypt jest rodzajem schematu poznawczego reprezentującym w umyśle rzeczywistość społeczną w formie zdarzeń i działań społecznych, w których występują: posiadający swoje cele aktorzy, warunki inicjujące wydarzenia, przeszkody i sposoby ich przezwyciężenia. 
i uwarunkowaniami ich realizacji. Co więcej, UTO nie mają charakteru uniwersalnego. W odmiennych sferach życia (np. rodzinna, zawodowa, publiczna) konstruowane są odrębne, alternatywne UTO. To dowodzi, że UTO nie są izolowanymi, pojedynczymi twierdzeniami, lecz zostają powiązane $\mathrm{w}$ ramach metatematów, reprezentujących różne sfery życia społecznego i zasiedlanych przez różne kategorie aktorów z charakterystycznymi dla nich, wzajemnie się warunkującymi dążeniami i celami ${ }^{59}$. Twierdzenia składające się na UTO jawią się więc jako zaledwie jeden z elementów szerszego konstruktu poznawczego, są pochodną jego metatematycznego rdzenia, epifenomenem wyobrażenia o dążeniach występujących w nim aktorów. UTO przypominają zatem to, co w swoich późniejszych pracach określa Trzebiński mianem schematu narracyjnego czy modelu dramaturgicznego.

Daniel Hutto stwierdza bardzo kategorycznie, i nie jest w tym odosobniony, że psychologia potoczna jest szczególnym rodzajem praktyki narracyjnej. Wspierając się ustaleniami innych badaczy, twierdzi, że starając się zrozumieć zachowania ludzi, odwołujemy się nie tylko do prostych atrybucji, wyjaśniających zachowania ludzi z perspektywy żywionych przez nich przekonań i pragnień, lecz tworzymy na ich temat narrację składającą się na bardziej szczegółową historię danej osoby. Katalog ludzkich motywów jest bowiem znacznie szerszy niż tylko pragnienia i przekonania i by je zrozumieć, konieczne jest uchwycenie detali indywidualnej historii. Starając się zrozumieć postępowanie innych, zwłaszcza w sytuacji, gdy ktoś przekracza i łamie jakieś normy i zasady, konstruujemy coś, co Hutto określa mianem "potoczno-psychologicznych narracji” (folk psychological narratives). Domniemane motywy są z tego punktu widzenia umieszczane w szerszej perspektywie jako elementy prawdopodobnej fabuły zdarzeń ${ }^{60}$.

To, co łączy obie zarysowane wyżej perspektywy, to fakt, że pozwalają one traktować poszczególne twierdzenia składające się na wiedzę potoczną jako zjawisko pochodne, wygenerowane przez głębszą i bardziej złożoną strukturę poznawczą o charakterze narracyjnym. Jeżeli twierdzenie to przeniesiemy teraz na wiedzę antropodoksalną, możemy podjąć próbę odkrycia narracji kryjących się za pojedynczymi sądami o człowieku i owe sądy generujących. Antropodoksa w tym też różna byłaby od psychologii potocznej. Zamiast pojedynczych, dymensjonalnych sądów miałaby charakter syntezujący, przybierałaby formę narracji, w której sądy te są zakorzenione.

Metoda rekonstrukcji treści antropodoksalnych, czy mówiąc konkretniej: narracji antropodoksalnej, narzuca się sama - metoda narracyjna. Jest ona

skutecznym narzędziem badania poglądów i postaw. Zdaniem wielu badaczy, pozwala ona uaktywnić naturalny dla badanego kontekst dla wygłaszanych poglądów i w ten sposób sprawić, że otrzymane dane trafnie świadczyć będą o rzeczywistych poglądach i sposobach rozumowania [...]. W szczególności metoda

59 J. Trzebiński, Reprezentacje skryptopodobne jako formy „ukrytych teorii osobowości”, [w:] Poznawcze regulatory funkcjonowania społecznego, red. J. Jarymowicz, Z. Smoleńska, Wrocław 1983, s. 11-48.

60 D. Hutto, Folk Psychological Narratives. The Sociocultural Basis of Understanding Reasons, Cambridge-London 2003, s. 1-21; S. Gallagher, D. Hutto, Understanding Other through Primary Interaction and Narrative Practice, [w:] The Shared Mind: Perspectives on Intersubjectivity, red. J. Zlatev et al., Amsterdam 2008, s. 25-28; P. Goldie, There are Reasons and Reasons, [w:] Folk Psychology Re-Assessed, red. D. Hutto, M. Ratcliffe, Springer 2007, s. 111-112. 
narracyjna ułatwia wypowiedzi jednostki mające charakter ogólnych poglądów — opowiadanie jest wtedy sposobem na ukonkretnienie tematów zbyt abstrakcyjnych w porównaniu z jej życiem codziennym

- pisze Trzebiński ${ }^{61}$. Sposób przeprowadzenia takiej analizy/rekonstrukcji treści może być oczywiście różny, różne są bowiem metody badań narracyjnych. Warto jednak podkreślić, że przedmiotem analizy może, a nawet powinna być nie tylko zawartość treściowa, ale również jej właściwości strukturalne. Związane z tym zagadnieniem szczegółowe rozważania metodologiczne to materia na osobny artykuł, jednakże badania w tym zakresie, $\mathrm{z}$ racji skupienia na punkcie widzenia aktora, plasując się $\mathrm{w}$ antynaturalistycznym, hermeneutycznym paradygmacie nauki o polityce, stanowić będą pewien wariant interpretacjonizmu.

\section{Podsumowanie}

Zaprezentowana wyżej kategoria antropodoksy, jak również inne formy i obszary myślenia potocznego, są moim zdaniem interesującym z politologicznej perspektywy obszarem badawczym. Biorąc bowiem pod uwagę strukturalno-funkcjonalne powiązania pomiędzy świadomością i działaniem, analiza każdej formy i treści wiedzy może wnieść istotny wkład w zrozumienie dynamiki postaw i preferencji politycznych, działań, zachowań czy też bardziej złożonych procesów zachodzących w sferze relacji władzy. Znając treść przekonań antropodoksalnych, możemy podjąć próbę przewidywania kierunków działań podmiotów będących jej nosicielami, rozkładu preferencji politycznych, sposobu wartościowania decyzji i rozwiązań polityczno-ustrojowych, siły ich legitymizacji i utożsamiania się z nimi. Ma to również wymiar praktyczny - marketingowy. Jeżeli jakiś projekt, siła polityczna, program bądź doktryna, lub chociaż ich elementy, współbrzmią z określoną antropodoksą, zawierają elementy korespondujące z potocznymi przekonaniami o naturze ludzkiej, to mogą one potencjalnie liczyć na wsparcie i mobilizację nosicieli tych przekonań. Jeżeli, przykładowo, jednym ze składników antropodoksy jest przekonanie o naturalnej i trwałej skłonności człowieka do zła, wynikającej np. z grzechu pierworodnego, to dla osoby żywiącej takie przekonanie potencjalnie atrakcyjny i uzasadniony będzie projekt ustrojowy odwołujący się do silnej, karzącej władzy, podkreślającej potrzebę respektowania i egzekwowania surowych i jednoznacznych standardów moralnych jako środka zapobiegania degeneracji i upadkowi społeczeństwa i kultury. Wskazane wyżej kierunki zastosowania prezentowanej kategorii analitycznej wymagają jednak empirycznej weryfikacji stawianych w tekście tez.

61 J. Trzebiński, Problematyka narracji we wspótczesnej psychologii, [w:] Narracja. Teoria i praktyka, red. B. Janusz, K. Gdowska, B. de Barbaro, Kraków 2008, s. 14. 


\section{Bibliografia}

Białek A., Patrz gdzie patrzę. Psychologiczne aspekty podejmowania cudzej perspektywy, Wydawnictwo Uniwersytetu Jagiellońskiego, Kraków 2010.

Bobryk J., Teoretyczny punkt wyjścia: czynności spostrzegania i interpretowania, wytwory tych czynności, dyspozycje psychiczne je determinujace, [w:] Percepcja i interpretacja społecznej i politycznej sytuacji w Polsce, red. I. Kurcz, J. Bobryk, Wydawnictwo Instytutu Psychologii, Warszawa 1997.

Bodio T., Świadomość a zachowania polityczne, Instytut Wydawniczy Związków Zawodowych, Warszawa 1989. Bodnar A., Nauka o polityce. Podręcznik akademicki, Państwowe Wydawnictwo Naukowe, Warszawa 1988.

Bruner J., The Acts of Meaning, Harvard University Press, Cambridge-London 2002.

Bruner J., Actual Minds, Possible Worlds, Harvard University Press, Cambridge-London 1986.

Coreth E., Czym jest antropologia filozoficzna?, „Studia Filozoficzne” 1983, nr 4.

Czajowski A., Decydowanie w polityce, Atla 2, Wrocław 2013.

Eccleshall R. et al., Political Ideologies. An Introduction, Routledge, London-New York 2003.

Encyklopedia politologii, t. 1, red. W. Sokół, M. Żmigrodzki, Kantor Wydawniczy Zakamycze, Kraków 1999.

Feldman R.S., Social Psychology. Theories, Research and Applications, McGrew-Hill Book Company, New York 1985.

Fletcher G.J.O., Psychologia a zdrowy rozsądek, „Nowiny Psychologiczne” 1985, nr 9-10.

Gallagher S., Hutto D., Understanding Other through Primary Interaction and Narrative Practice, [w:] The Shared Mind: Perspectives on Intersubjectivity, red. J. Zlatev et al., John Benjamins, Amsterdam 2008.

Garfinkel H., Aspekt problemu potocznej wiedzy o strukturach społecznych, [w:] Fenomenologia i socjologia. Zbiór tekstów, red. Z. Krasnodębski, Wydawnictwo PWN, Warszawa 1989.

Gehlen A., W kręgu antropologii i psychologii społecznej, Czytelnik, Warszawa 2001.

Goldie P., There are Reasons and Reasons, [w:] Folk Psychology Re-Assessed, red. D. Hutto, M. Ratcliffe, Springer, Dordrecht 2007.

Grzegorek T., Czy jeszcze jest psychologia potoczna?, „Studia Psychologiczne” 2011, nr 49.

Heider F., The Psychology of Interpersonal Relations, John Wiley \& Sons Inc., New York-London 1964.

Heywood A., Teoria polityki. Wprowadzenie, Wydawnictwo Naukowe PWN, Warszawa 2009.

Horonziak S., Institutions as the forces of stabilizing state. Contemporary look at the Arnold Gehlen's theory of institutions, „Political Dialogues” 2015, nr 18.

Hutto D., Folk Psychological Narratives. The Sociocultural Basis of Understanding Reasons, A Bradford Book, The MIT Press, Cambridge-London 2003.

International Encyclopedia of the Social \& Behavioral Science, t. 11, red. N.J. Smelser, P.B. Baltes, Elsevier, Amsterdam 2001.

Jawłowska A., Wstęp, [w:] Kategoria potoczności. Źródła filozoficzne i zastosowania teoretyczne, red. eadem, Instytut Kultury, Warszawa 1991, s. 5-13.

Karwat M., Malinowski W., Działania polityczne jako składnik systemu praktyki społecznej, [w:] Elementy teorii polityki, red. K. Opałek, Państwowe Wydawnictwo Naukowe, Warszawa 1989, s. 110-127.

Kimla P., Arnold Gehlen w obronie instytucji i klasycznych zadań władzy i instytucji państwa, „Państwo i Społeczeństwo" 2005, nr 1.

Kofta M., Procesy atrybucji w spostrzeganiu społecznym, [w:] Psychologia spostrzegania społecznego, red. M. Lewicka, Książka i Wiedza, Warszawa 1985.

Kostecki W., Ideologia polityczna jako forma świadomości społecznej, [w:] Elementy teorii polityki, red. K. Opałek, Państwowe Wydawnictwo Naukowe, Warszawa 1989.

Kozielecki J., Koncepcje psychologiczne człowieka, Wydawnictwo Akademickie „Żak”, Warszawa 2000.

Krasnodębski Z., Ekscentryczność człowieka. O idei antropologii filozoficznej, [w:] H. Plessner, Spór o conditio humana, Państwowy Instytut Wydawniczy, Warszawa 1988.

Kurcz I., Psychologia poznawcza, [w:] Psychologia a semiotyka: pojęcia i zagadnienia, red. eadem, Zakład Semiotyki Logicznej UW, Warszawa 1993. 
Lachowicz-Tabaczek K., Potoczne koncepcje świata i natury ludzkiej. Ich wplyw na poznanie i zachowanie, Gdańskie Wydawnictwo Psychologiczne, Gdańsk 2004.

Lachowicz-Tabaczek K., Przekonania o naturze ludzkiej jako element stylu regulacji zachowania, „Studia Psychologiczne" 2002, $\mathrm{nr} 4$.

Leksykon politologii, red. A. Antoszewski, R. Herbut, Atla 2, Wrocław 1997.

Lewicka M., Wojciszke B., Wiedza jednostki i sady o świecie społecznym, [w:] Psychologia. Podręcznik akademicki, red. J. Strelau, t. 3, Gdańskie Wydawnictwo Akademickie, Gdańsk 2000.

Lewicki P., Zjawisko „ukrytej teorii osobowości” w procesie spostrzegania społecznego, [w:] Psychologia spostrzegania społecznego, red. M. Lewicka, Książka i Wiedza, Warszawa 1985.

Łukaszewski W., Psychologia podzielona, „Nauka” 2011, nr 4.

Łukaszewski W., Psychologiczne koncepcje człowieka, [w:] Psychologia. Podręcznik akademicki, red. J. Strelau, t. 2, Gdańskie Wydawnictwo Psychologiczne, Gdańsk 2000.

Łukaszewski W., Wielkie pytania psychologii, Smak Słowa, Sopot 2015.

Łukaszewski W., Weigl B., Stereotyp stereotypu czy prywatna koncepcja natury ludzkiej?, [w:] Stereotypy i uprzedzenia. Uwarunkowania psychologiczne i kulturowe, red. M. Kofta, A. Jasińska-Kania, Wydawnictwo Naukowe Scholar, Warszawa 2001.

Malewska-Szałygin A., Zarys tradycji stosowania pojęcia „wiedza potoczna”, „Etnografia Polska” 1995, nr 1-2.

Michalski R., Homo defectus w kulturze późnej nowoczesności, Wydawnictwo Naukowe UMK, Toruń 2013.

Najder K., Reprezentacja poznawcza we wspótczesnej psychologii, [w:] Psychologia a semiotyka: pojęcia i zagadnienia, red. I. Kurcz, Zakład Semiotyki Logicznej UW, Warszawa 1993.

Neisser U., Cognitive Psychology, Appleton Century Crafts, New York 1967.

Plessner H., Władza a natura ludzka. Esej o antropologii światopoglądu historycznego, Wydawnictwo Naukowe PWN, Warszawa 1994.

Pluskiewicz W., Świadomość polityczna - analiza strukturalna, Wydawnictwo Politechniki Śląskiej, Gliwice 1992.

Polkinghorne D.E., Narrative Knowing and the Human Science, State University of New York Press, Albany 1988.

Psychologia poznawcza, red. E. Nęcka, Wydawnictwo Instytutu Psychologii PAN, Warszawa 1997.

Ravenscroft I., Folk Psychology as a Theory, https://plato.stanford.edu/archives/fall2010/entries/folkpsychtheory/\#P (dostęp: 28 lutego 2017).

Rehberg K.-S., Antropologia działania i teoria porzadku Arnolda Gehlena, [w:] Konserwatyzm. Projekt teoretyczny, red. B. Markiewicz, Wydawnictwo Polskiego Towarzystwa Filozoficznego: Goethe Institut, Warszawa 1985.

Reykowski J., Myślenie polityczne, [w:] Podstawy psychologii politycznej, red. K. Skarżyńska, Wydawnictwo Zysk i S-ka, Poznań 2002.

Rudnicki K., Teoriopolityczna analiza subiektywnego kontekstu działań politycznych na przykładzie doktryn politycznych, [w:] Elementy teorii polityki, red. K. Opałek, Państwowe Wydawnictwo Naukowe, Warszawa 1989.

Rügemer W., Główne dzieło Gehlena „Der Mensch“ i mit antropologii empiryczno-biologicznej, „Studia Filozoficzne" 1983, nr 8-9.

Ryszka F., Nauka o polityce. Rozważania metodologiczne, Państwowe Wydawnictwo Naukowe, Warszawa 1984.

Ryszka F., Wstęp do nauki o polityce. Uwagi metodologiczne, Państwowe Wydawnictwo Naukowe, Warszawa-Poznań 1984.

Scheler M., Pisma z antropologii filozoficznej i teorii wiedzy, PWN, Warszawa 1987.

Siemianowski A., Antropologia filozoficzna, Prymasowskie Wydawnictwo Gaudentinum, Gniezno 1996.

Skarżyńska K., Człowiek a polityka. Zarys psychologii politycznej, Wydawnictwo Naukowe Scholar, Warszawa 2005.

Sobkowiak L., Działania polityczne. Teoria i praktyka, [w:] Marketing polityczny w teorii i praktyce, red. A.W. Jabłoński, L. Sobkowiak, Wydawnictwo Uniwersytetu Wrocławskiego, Wrocław 2002, s. 11-44. 
Sobkowiak L., Świadomość i socjalizacja polityczna, [w:] Studia z teorii polityki, red. A.W. Jabłoński, L. Sobkowiak, t. 1, Wydawnictwo Uniwersytetu Wrocławskiego, Wrocław 1999.

Stich S.P., Nichols S., Folk Psychology, [w:] The Blackwell Guide to Philosophy of Mind, red. S.P. Stich, T.A. Warfiled, Blackwell Publishing, Malden 2003.

Tower Sargent L., Political Ideologies. A Comparative Analysis, Cengage Learning, Wadsworth 2009.

Trzebiński J., Narracyjne formy wiedzy potocznej, Wydawnictwo Nakom, Poznań 1992.

Trzebiński J., Narracyjne konstruowanie rzeczywistości, [w:] Narracja jako sposób rozumienia świata, red. idem, Gdańskie Wydawnictwo Psychologiczne, Gdańsk 2002.

Trzebiński J., Problematyka narracji we współczesnej psychologii, [w:] Narracja. Teoria i praktyka, red. B. Janusz, K. Gdowska, B. de Barbaro, Wydawnictwo Uniwersytetu Jagiellońskiego, Kraków 2008.

Trzebiński J., Reprezentacje skryptopodobne jako formy „ukrytych teorii osobowości”, [w:] Poznawcze regulatory funkcjonowania społecznego, red. J. Jarymowicz, Z. Smoleńska, Wydawnictwo Polskiej Akademii Nauk, Wrocław 1983.

Trzebiński J., Rola schematów poznawczych w zachowaniach społecznych, [w:] Psychologia spostrzegania społecznego, red. M. Lewicka, Książka i Wiedza, Warszawa 1985.

Valverde C., Antropologia filozoficzna, Pallotinum, Poznań 1998.

Wojciszke B., Teoria schematów społecznych. Struktura i funkcjonowanie jednostkowej wiedzy o otoczeniu społecznym, Zakład Narodowy im. Ossolińskich, Wrocław 1986.

Wojciszke B., Doliński D., Psychologia społeczna, [w:] Psychologia. Podręcznik akademicki, red. D. Doliński, J. Strelau, t. 2, Gdańskie Wydawnictwo Psychologiczne, Gdańsk 2008.

Wróbel S., Zachowanie i działanie polityczne, [w:] Wprowadzenie do nauki o państwie i prawie, red. B. Szmulik, M. Żmigrodzki, Wydawnictwo UMCS, Lublin 2007.

\section{Political anthropodoxis as a theoretical category and object of analysis}

Keywords: anthropodoxis, folk anthropology, narrative, common-knowledge, human nature, folk psychology

\section{Summary}

The article presents a meaning of the notion "political anthropodoxis" and justifies its analytical separation. The title category, inspired by the structure of philosophical anthropology thought and findings in folk psychology, is first placed into the system of political theory concepts. Its subsequent detailed characteristics is followed by outlined methodological perspective appropriate for its analysis. 